\title{
EDITORIAL
}

\section{By All Available Means: New Takes on Established Principles, Actions and Institutions to Address Today's Environmental Challenges}

\section{INTRODUCTION}

With international negotiations under way to promulgate the Sustainable Development Goals (SDGs) and a post-2020 climate change agreement anticipated by the end of this year, 2015 promises to be a milestone for environmental governance. The process to develop the SDGs, which will build upon the Millennium Development Goals and converge with the broader United Nations (UN) post-2015 development agenda, was launched at the June 2012 UN Conference on Sustainable Development (UNCSD), better known as Rio+20. ${ }^{1}$ Thus far, the process has been an exemplary model of public participation. The UN has conducted the largest consultation programme in its history and has used a range of mechanisms, including traditional working groups, national consultations, and an online global survey to ascertain what the SDGs should include. The SDGs comprise 17 goals, within which are a proposed 169 targets. They are expected to be finalized and adopted at the UN Sustainable Development Summit in September 2015. ${ }^{2}$

At the same time, the negotiations for the $21^{\text {st }}$ session of the Conference of the Parties (COP-21) to the United Nations Framework Convention on Climate Change (UNFCCC), ${ }^{3}$ to be held in Paris in December 2015, have been proceeding apace. At the sixth Petersberg Climate Dialogue in May 2015, German Chancellor Angela Merkel emphasized that climate finance will be a decisive factor in whether the Paris COP-21 is a success or a failure. ${ }^{4}$ In this regard, it is noteworthy that the Green Climate Fund became operational on 21 May 2015; it can now begin to select and fund projects, which, it is hoped, will bolster the confidence and trust of developing countries ahead of

1 Rio de Janeiro (Brazil), 20-22 June 2012, available at: http://www.uncsd2012.org/about.html.

2 See the discussion and interactive map of the SDGs in 'Sustainable Development Goals: Changing the World in 17 Steps - Interactive', 19 Jan. 2015, The Guardian, available at: http://www.theguardian.com/ global-development/ng-interactive/2015/jan/19/sustainable-development-goals-changing-world-17-stepsinteractive. The Zero draft of the SDGs is available at: https://sustainabledevelopment.un.org/? page $=$ view $\&$ nr $=829 \&$ type $=230 \&$ menu $=2059$.

3 New York, NY (US), 9 May 1992, in force 21 Mar. 1994, available at: http://unfccc.int.

4 Petersberg Climate Dialogue VI, Berlin (Germany), 17-19 May 2015, 'Reaching for the Paris Outcome', available at: http://www.bmub.bund.de/en/topics/climate-energy/climate/international-climate-policy/ petersberg-climate-dialogue. 
the Paris conference. ${ }^{5}$ Furthermore, at the time of writing, 21 jurisdictions - including the European Union (EU), China, and the United States (US) - have submitted their Intended Nationally Determined Contributions (INDCs), which are the post-2020 climate actions that states publicly commit to undertake pursuant to the new international agreement. ${ }^{6}$ As of July 2015, it is estimated that the INDCs pledged thus far will reduce emissions amounting to only 17 to $19 \%$ of the 'emissions gap' between the global emissions level in 2030 that would be consistent with achieving the internationally agreed target of two degrees Celsius $\left(2^{\circ} \mathrm{C}\right)$ and those that would result from current policies. ${ }^{7}$ Against this background, the contributions in this issue of TEL by John Dernbach and Federico Cheever, Evadné Grant and Onita Das, Joana Setzer, Ernesto Roessing Neto, and Josephine van Zeben challenge conventional conceptions and approaches towards addressing sustainable development and climate change.

Another overarching theme of the SDGs process and the climate negotiations is the evolution of institutions to address a widening range of social and environmental risks. Following a period of the proliferation of multilateral environmental agreements, which gave rise to concerns about their fragmentation and effectiveness, a growing body of scholarship now advocates strengthening and enhancing the coherence of existing treaty regimes. ${ }^{8}$ The Arctic Ocean Coordinating Agreement proposed by Betsy Baker and Brooks Yeager, presented in this issue, exemplifies this alternative approach to regime building. Completing the line-up for this issue of TEL is an article by Joshua Gellers, in which the author uses social scientific methods of analysis to shed light on the contextual factors that explain the inclusion (or not) of environmental rights in national constitutions. This responds to a key part of TEL's mission, to encourage inter-disciplinary research and dialogue to enhance our collective understanding of the role that law can play to tackle contemporary environmental problems. Finally, it is noteworthy that the articles and commentaries that make up this issue of TEL are impressively geographically diverse. This geographical reach bears testimony to the claim that transnational environmental law is neither a Eurocentric nor transatlantic intellectual project, but one that offers a globally relevant set of concepts to analyze the multifarious aspects of cross-border environmental law and policy, occurring at different scales and involving multiple actors.

\section{SUSTAINABLE DEVELOPMENT}

In 'Sustainable Development and Its Discontents', John Dernbach and Federico Cheever observe that the original meaning of sustainable development as 'a form of

5 Green Climate Fund, 'GCF Reaches Effectiveness, Can Begin Allocating Resources Ahead of Paris Climate Conference', Press Release, 21 May 2015, available at: http://news.gcfund.org/wp-content/ uploads/2015/05/GCF_press_release_21_may_2015.pdf.

6 UNFCCC Secretariat, 'Intended Nationally Determined Contributions (INDCs)', available at: http://unfccc.int/focus/indc_portal/items/8766.php.

7 PBL Netherlands Environmental Assessment Agency, 'PBL Climate Pledge INDC Tool', available at: http://infographics.pbl.nl/indc. For a discussion of the history of the $2^{\circ} \mathrm{C}$ target, see S. Randalls, 'History of the 2C Climate Target' (2010) 1 WIREs Climate Change, pp. 598-605.

8 K.W. Abbott, 'Strengthening the Transnational Regime Complex for Climate Change' (2014) 3(1) Transnational Environmental Law, pp. 57-88; H. van Asselt, 'Managing the Fragmentation of International Environmental Law: Forests at the Intersection of the Climate and Biodiversity Regimes' (2012) 44(4) New York University Journal of International Law and Politics, pp. 1205-78. 
development' with 'integrated decision making for human well-being ... at its core' has been obscured and subsequently misunderstood by its critics. ${ }^{9}$ They provide a historically grounded analysis of the meaning of sustainable development. They emphasize that sustainable development is not a legal framework. It is a 'normative conceptual framework ... Yet, just as other normative ideas such as freedom, equality, and justice have been written into law, so sustainable development is being written into law'. ${ }^{10}$ As a framework to aid decision making, Dernbach and Cheever argue that 'the central conceptual achievement of sustainable development is to offer an alternative to the binary "environment or development" narratives that have traditionally dominated public and private political discourse'. ${ }^{11}$ Their in-depth analysis puts the authors in a position to constructively respond to three categories of critics, who think that sustainable development is either 'too boring', 'too vague', or 'too late' to be successful.

In response to the first critique, which views sustainability as a 'damage control term' incapable of inspiring action that will reverse current trends towards greater environmental degradation, ${ }^{12}$ Dernbach and Cheever point out that potentially catchier concepts like 'abundance' or 'thriveability' may work in fields such as urban planning and architecture, but cannot substitute sustainable development as a policy decision-making framework. ${ }^{13}$ As to the second group of critics, the crux of the authors' response is that the critiques of sustainable development as being 'too vague' to be a meaningful concept 'are less about ... sustainable development' as understood through its history 'than they are about how some individuals and organizations apply the term'. ${ }^{14}$ Finally, in response to the critics who argue that resilience is more realistic and appropriate than sustainability given that 'current and future conditions make sustainable development impossible', Dernbach and Cheever remind us that 'resilience allows us to turn a blind eye to social justice. Sustainability does not'. 15

Dernbach and Cheever emphasize that the foundational action principle of sustainable development is integrated decision making, and that there are different kinds of integration. ${ }^{16}$ In their article, 'Land Grabbing, Sustainable Development and Human Rights', Evadné Grant and Onita Das put integration at the heart of their argument. ${ }^{17}$ They argue that the principles of sustainable development are reinforced and complemented by international human rights law and that a combined sustainable development and human rights framework has the potential to more effectively balance economic development, social justice and environmental protection in the context of

9 J. Dernbach \& F. Cheever, 'Sustainable Development and Its Discontents' (2015) 4(2) Transnational Environmental Law, pp. 247-87, at 251.

10 Ibid., at p. 251.

11 Ibid., at p. 263.

12 Ibid., at p. 270.

13 Ibid.

14 Ibid., at p. 277.

15 Ibid., at pp. 279-80.

16 Ibid., at p. 259.

17 E. Grant \& O. Das, 'Land Grabbing, Sustainable Development and Human Rights' (2015) 4(2) Transnational Environmental Law, pp. 289-317. 
land grabbing'. ${ }^{18}$ Land grabbing has generated much debate in recent years. Olivier De Schutter, former UN Special Rapporteur on the Right to Food, describes land grabbing as 'a global enclosure movement in which large areas of arable land change hands through deals often negotiated between host governments and foreign investors with little or no participation from the local communities who depend on access to those lands for their livelihoods'. ${ }^{19}$

Land grabbing raises significant concerns, such as the forced relocation of local communities in order to clear land for investors, violation of land rights, food insecurity, environmental damage resulting from large-scale industrial farming practices, and water insecurity when unregulated water use leads to over-extraction. ${ }^{20}$ Using Ethiopia as a case study, Grant and Das discuss these problems caused by land grabbing and analyze the aspects of sustainable development and international human rights law that are most salient to land grabbing. The authors argue that ' $[t]$ here is growing agreement that the core principles of sustainable development encompass sustainable use of natural resources, common but differentiated responsibilities (CBDRs), the precautionary principle, public participation, good governance and inter-generational equity'. ${ }^{21}$ However, in their view, sustainable development 'implicitly supports the neoliberal idea of competitive markets and ... the development aspect often overwhelms concern for the other dimensions of sustainability'. ${ }^{2}$ 'In the context of land grabbing, the problem of the skewing of priorities towards economic development and the lack of integration of ecological sustainability and social justice emerges most clearly'. ${ }^{23}$ Grant and Das see a role for international human rights law in balancing the three pillars of sustainable development. In the context of land grabbing, they highlight 'promising developments in three areas: soft law, human rights litigation, and land rights' ${ }^{24}$ Soft law instruments such as the UN Food and Agriculture Organization ${ }^{25}$ (FAO) Voluntary Guidelines for Responsible Governance of Tenure of Land, Fisheries, and Forest in the Context of Food Security, and voluntary certification schemes such as the Roundtable on Sustainable Palm Oil (RSPO) ${ }^{26}$ can provide guidance to corporations as well as to governments. Moreover, with sufficient support from governments, local communities, civil society and business, soft law may be transformed into national law. ${ }^{27}$ Grant and Das also see promise in human rights litigation to legally enforce sustainable development principles. They point out that 'the relatively wide scope of the African human rights system ... clearly facilitates claims that may arise from ... land grabbing, including environmental damage and impacts on the health and wellbeing of affected

18 Ibid., at p. 291.

19 Quotation reproduced in ibid., at p. 289.

20 See discussion, ibid., at Section 3, pp. 294-8.

21 Ibid., at p. 299.

22 Ibid., at p. 306.

23 Ibid., at p. 307.

24 Ibid., at p. 311.

25 FAO, Voluntary Guidelines for Responsible Governance of Tenure of Land, Fisheries, and Forest in the Context of Food Security (FAO, 2012).

26 RSPO, Principles and Criteria for Sustainable Palm Oil Production (RSPO, 2013).

27 Grant \& Das, n. 17 above, at p. 311. 
communities'. ${ }^{28}$ However, they also recognize the 'significant weaknesses in the system, including delays in deciding cases and weak enforcement of judgments'. ${ }^{29}$ Finally, the authors advocate the clarification of land rights to prevent land grabbing. They consider a number of options, including individual titling, but also recognize that there are many issues at stake in developing locally appropriate approaches to land rights. ${ }^{30}$

\section{BEYOND INTERSTATE RESPONSES TO CLIMATE CHANGE}

Many scholars perceive climate change to be a classic example of the Tragedy of the Commons. ${ }^{31}$ Like the open pasture in Garrett Hardin's example, ${ }^{32}$ the atmosphere is being 'overexploited' by every state on this planet contributing greenhouse gas (GHG) emissions as a byproduct of activities such as energy generation and agriculture. Following Hardin, there are only two ways to avert the impending tragedy privatization of the resource or regulation to protect the resource. ${ }^{33}$ In the case of climate change, privatization occurs chiefly through the establishment of emissions trading systems and regulation is pursued through globally moderated emissions limits. ${ }^{34}$ In accordance with this dominant perspective, climate change has been cast as a global problem requiring a global solution. As such, there is no obvious role for subnational governments to play in tackling climate change. Yet cities, provinces and states in federal regimes have been proactively implementing climate change policies, often in the absence of national initiatives. This has given rise to local climate change law, and is also viewed as part of the growing trend of paradiplomacy, a term which refers to international activity performed by subnational governments. ${ }^{35}$

In 'Testing the Boundaries of Subnational Diplomacy: The International Climate Action of Local and Regional Governments', Joana Setzer notes that researchers have provided explanations for why subnational governments become involved in climate action and the outcomes of their participation, but that the scholarship 'takes for granted the legal competence of subnational entities to undertake international relations. ${ }^{36}$ Her article examines the legal context in which subnational climate

28 Ibid., at pp. 312-13.

29 Ibid., at p. 314.

30 Ibid., at pp. 316-17.

31 E.g., R.N. Stavins, 'Policy Instruments for Climate Change: How Can National Governments Address a Global Problem?' (1997) University of Chicago Legal Forum, pp. 293-329; D.H. Cole, 'From Global to Polycentric Climate Governance' (2011) 2 Climate Law, pp. 395-413: 'Climate change is the greatest collective action problem the international community has ever confronted': ibid., at p. 395.

32 G. Hardin, 'The Tragedy of the Commons' (1968) 162(3859) Science, pp. 1243-8.

33 In support of privatization, see H. Demsetz, 'Toward a Theory of Property Rights' (1967) 57(2) The American Economic Review, pp. 347-59. In support of centralized governance, see ibid.

34 K.H. Engel \& S.R. Saleska, 'Subglobal Regulation of the Global Commons: The Case of Climate Change' (2005) 32 Ecology Law Quarterly, pp. 183-233, at 191.

35 B.J. Richardson (ed.), Local Climate Change Law: Environmental Regulation in Cities and Other Localities (Edward Elgar, 2012); E. Roessing Neto, 'Linking Subnational Climate Change Policies: A Commentary on the California-Acre Process' (2015) 4(2) Transnational Environmental Law, pp. 425-37, at 431.

36 J. Setzer, 'Testing the Boundaries of Subnational Diplomacy: The International Climate Action of Local and Regional Governments' (2015) 4(2) Transnational Environmental Law, pp. 319-37, at 320 . 
diplomacy takes place, and shows that if cities and regions are to help in addressing the inadequacies of the international climate regime, then domestic and international legal frameworks will need to further accommodate subnational diplomatic activities' ${ }^{37}$ Setzer suggests that the international activities that local and regional governments undertake usually fall into two broad categories: collaboration and coalition initiatives. 'In collaboration initiatives, local and regional governments collaborate with other subnational, national or international actors. In coalition initiatives, local and regional governments exert pressure over national and international actors' ${ }^{38}$ In Setzer's view, both types of activity 'invite a crucial question: by engaging in subnational diplomacy, to what extent are local and regional governments exceeding their legal authority? 39

Setzer concludes that international law does not recognize subnational governments as possessing legal personality, ${ }^{40}$ whereas domestic law governing paradiplomacy differs from state to state. Setzer presents a fascinating account of how some countries, in particular Brazil, have legislated explicitly on the capacity of subnational governments to engage in international relations. By renaming paradiplomacy " "federative diplomacy" - a term that expresses the intention of decentralizing the country's diplomacy', the Brazilian federal government created the political space for subnational governments to undertake international initiatives. ${ }^{41}$ However, Setzer concludes that ' $\mathrm{t}$ ] o a certain extent, federative diplomacy is a way for the federal government to control, rather than to give independence to, subnational governments' international agendas' ${ }^{42}$ Setzer argues that, ultimately, domestic and international legal frameworks must move beyond state-centric categorizations and 'appreciate the emergence of subnational participation in global governance' if the entrepreneurial and innovative energy of cities and regions is to be tapped to address climate change.

An examination of a Brazilian subnational government's engagement in federative diplomacy, 'Linking Subnational Climate Change Policies: A Commentary on the California-Acre Process', explores the practical issues that arise from an attempt to link the climate change policies of California (US) and Acre (Brazil). ${ }^{43}$ The process that Roessing Neto analyzes is that of linking the Reduction of Emissions from Deforestation and Forest Degradation (REDD) scheme in Acre with the Californian GHG cap-andtrade programme. ${ }^{44}$ California's programme provides for the use of various compliance instruments, including offsets generated out of California. ${ }^{45}$ What is envisaged for the linking process is a unilateral flow of offsets generated by REDD activity in Acre into the

37 Ibid., at p. 320.

38 Ibid., at p. 326.

39 Ibid., at p. 327.

40 For an alternative perspective, see Y. Blank, 'The City and the World' (2006) 44(3) Columbia Journal of Transnational Law, pp. 868-931, at 870, arguing that localities are gradually acquiring status and standing in international law and within international organizations.

41 Setzer, n. 36 above, at p. 333.

42 Ibid., at p. 336.

43 Roessing Neto, n. 35 above.

44 Ibid., at pp. 427-8, 431.

45 Ibid., at p. 427. 
Californian market. ${ }^{46}$ As Roessing Neto notes, 'what is remarkable about the emerging linkage between California and Acre is the fact that, if concluded, it would establish a formal, legally binding system of rights and obligations, crafted through the acts of non-sovereign subnational jurisdictions located in different sovereign states'. ${ }^{47}$ Further, '[a]lthough paradiplomacy would not, in itself, establish this system of rights and obligations, it would be the means through which California and Acre manifest their political will and coordinate domestic actions in order to make the proposed linkage possible. Nevertheless, whenever paradiplomacy is used, there is a risk of disapproval by central governments'. ${ }^{48}$ The author delves into the domestic context to shed light on the positions of the respective central governments and points out that legal and political tools can be used to thwart this linkage. ${ }^{49}$ However, if successful, the California-Acre scheme will generate impact beyond the subnational level. Roessing Neto argues that it could influence the REDD negotiations within the UNFCCC framework as well as serve as a policy experiment for future US federal policy. ${ }^{50}$

Another alternative response to climate change that lies outside the UNFCCC regime has been litigation to hold governments and private corporations liable for the harm caused by their GHG emissions and/or to force them to take mitigation measures. Thus far, the vast majority of climate litigation has taken place in Australia, the US and the United Kingdom (UK). ${ }^{51}$ The landmark case of Stichting Urgenda v. Government of the Netherlands (Ministry of Infrastructure and the Environment) (Urgenda) has put the Netherlands on the climate change litigation 'map', occupying 'a unique position as the first decision to order a government to ensure the reduction of GHG emissions for reasons other than statutory mandate'. 52

In 'Establishing a Governmental Duty of Care for Climate Change Mitigation: Will Urgenda Turn the Tide?', Josephine van Zeben analyzes the Urgenda decision with a focus on its relevance to other jurisdictions. From the outset, it should be noted that the legal implications of the decision are unclear as there are several stages of appeal available to the Dutch government. ${ }^{53}$ Nevertheless, van Zeben argues that the judgment 'represents an important new chapter in climate change liability litigation, particularly in the EU, and therefore requires close inspection'.54

46 Ibid., at p. 428.

47 Ibid., at p. 431.

48 Ibid., at p. 433.

49 Ibid., at p. 436.

50 Ibid., at p. 435.

51 For discussion, see J. Peel \& H. Osofsky, 'Climate Change Litigation's Regulatory Pathways: A Comparative Analysis of the United States and Australia' (2013) 35(3) Law and Policy, pp. 150-83; S. Bogojevic, 'EU Climate Change Litigation: All Quiet on the Luxembourgian Front?', in G. Van Calster, W. Vandenberghe \& L. Reins (eds), Research Handbook of Climate Change Mitigation Law (Edward Elgar, 2015), pp. 543-59.

52 J. van Zeben, 'Establishing A Governmental Duty of Care for Climate Change Mitigation: Will Urgenda Turn the Tide?' (2015) 4(2) Transnational Environmental Law, pp. 339-57, at 347.

53 Ibid., at p. 341.

54 Ibid. 
The Dutch non-governmental organization (NGO) Urgenda argued that the Netherlands owed Urgenda and the rest of Dutch society a duty of care, breach of which violated Section 6:162 of the Dutch Civil Code (which governs the Dutch tort of negligence). ${ }^{55}$ Establishing causation has traditionally been a major hurdle for climate litigation since the traditional 'but for' test cannot be satisfied. What is notable about the Urgenda decision is the Dutch District Court's ruling that it was unnecessary for Urgenda to satisfy the 'but for' test. ${ }^{56}$ In considering the relevance of this decision for other jurisdictions, van Zeben points out that the Dutch court's treatment of causation in Urgenda differs significantly from that of English courts in comparable cases. ${ }^{57}$ She concludes that '[p]rovided the decision is not overturned on appeal, the extremely limited grounds for causation given by the Court could reduce its relevance for jurisdictions such as the UK, as it does not address many of the questions typically posed by courts in this jurisdiction'. ${ }^{58}$

Van Zeben similarly adopts a comparative approach to consider whether the Urgenda decision amounts to extraordinary judicial activism and whether courts in other jurisdictions, including the US, Canada and the UK, would respond similarly. She concludes that the Urgenda decision raises democratic concerns which should not be overlooked in 'the enthusiasm regarding the pro-environmental outcome of Urgenda [and] the perceived desirability of the outcome'. ${ }^{59}$ The article concludes that, ultimately, the key importance of Urgenda could be as a catalyst for academic, political and judicial discussion - what van Zeben refers to as Urgenda's 'signalling effect'. However, she cautions that the most powerful message may well be that court action 'cannot replace the democratic process, domestically or at the EU level'. ${ }^{60}$

\section{EVOLVING TRANSNATIONAL INSTITUTIONS}

Global warming has caused profound changes in the Arctic Ocean. Ice-diminished conditions have rendered possible an increase in human activities such as shipping, hydrocarbon exploration and development, tourism and fishing. ${ }^{61}$ In 'Coordinated Ocean Stewardship in the Arctic: Needs, Challenges and Possible Models for an Arctic Ocean Coordinating Agreement', Betsy Baker and Brooks Yeager highlight that the most immediate challenges facing the marine Arctic are conserving subsistence and wildlife opportunities in the face of climate-related stress to physical and ecological systems and managing increased human use of the Arctic environment. ${ }^{62}$ These issues present novel governance challenges for the eight Arctic nations: Canada, Denmark (on behalf of Greenland

55 Ibid., at p. 344.

56 Ibid., at pp. 348-9.

57 Ibid., at p. 351.

58 Ibid., at p. 352.

59 Ibid., at p. 356.

60 Ibid., at p. 357.

61 B. Baker \& B. Yeager, 'Coordinated Ocean Stewardship in the Arctic: Needs, Challenges and Possible Models for an Arctic Ocean Coordinating Agreement' (2015) 4(2) Transnational Environmental Law, pp. 359-94, at 360.

62 Ibid., at p. 380. 
and the Faroe Islands), Finland, Iceland, Norway, the Russian Federation, and the US.

To meet these challenges, the authors propose a model coordinating mechanism that draws on existing institutions, such as the Arctic Council, ${ }^{63}$ that are already successfully engaged in addressing problems relevant to the Arctic Ocean. ${ }^{64}$ This mechanism, for which they suggest the name 'Arctic Ocean Coordinating Agreement' (AOCA), could enhance the ability of the Arctic Council to coordinate national, regional and international management efforts in the Arctic 'without fundamentally changing its character, or itself becoming a management body'. ${ }^{65}$ The authors' vision of an AOCA is of a 'nimble, versatile body which operates without creating new institutions, focusing instead on convening existing individuals and institutions whose expertise can assist the Arctic states with marine management questions that the those states define'. ${ }^{66}$ What is most interesting about the authors' proposal is that it is pragmatic, does not require significant new institutional investments, and places importance on integration and coherence in a governance framework.

In an analysis that will be of much interest to policy makers, Baker and Yeager consider a set of questions that they believe are salient to the successful establishment of an AOCA: (i) the relationship between the AOCA and the Arctic Council; (ii) the AOCA's membership and how to involve non-parties on bases other than an observer basis; (iii) its spatial scope; and (iv) its substantive scope. ${ }^{67}$ They also identify specific mechanisms for regional marine cooperation that could be adapted for the Arctic Ocean without adopting the wider multilateral treaty or organization that created the mechanism. These mechanisms include the coordinating framework on which the Baltic Marine Environment Committee or Helsinki Commission (HELCOM) - established under the Convention on the Protection of the Marine Environment of the Baltic Sea Area (Helsinki Convention) ${ }^{68}$ - relies in responding to major maritime accidents, and the conservation efforts within the 2003 Framework Convention of the Marine Environment of the Caspian Sea (Tehran Convention). ${ }^{69}$ Finally, recognizing that actors apart from states and international organizations play an important role in environmental governance, the authors propose that an AOCA could draw upon the expertise of existing scientific NGOs to improve the coordination of research, monitoring and assessment projects and to provide a formal process for better inter-treaty and inter-institutional linkages. $^{70}$

63 Ibid., at pp. 367, 394.

64 Ibid., at p. 360.

65 Ibid., at p. 394.

66 Ibid., at p. 380.

67 Ibid., at Section 2, pp. 372-80.

68 Helsinki (Finland), 9 Apr. 1992, in force 17 Jan. 2000, available at: http://tinyurl.com/ Helsinki-Convention.

69 Tehran (Iran), 4 Nov. 2003, in force 12 Aug. 2006, available at: http://www.tehranconvention.org; Baker \& Yeager, n. 61 above, at pp. 383, 386-7.

$70 \quad$ Ibid., at p. 389. 


\section{USING SOCIAL SCIENCES RESEARCH METHODS IN LEGAL SCHOLARSHIP}

As Joshua Gellers writes in the introduction to 'Environmental Constitutionalism in South Asia: Analyzing the Experiences of Nepal and Sri Lanka', much of the scholarship on the constitutional adoption of environmental rights is discussed mainly in normative and descriptive terms. ${ }^{71}$ Few have sought to explain the emergence of constitutional environmental rights in the context of specific cases using social scientific methods of analysis. ${ }^{72}$ Through a comparative study of Nepal and Sri Lanka, Gellers identifies the historical and structural factors that influence the likelihood that a given country might explicitly include human rights to the environment within its governing charter. These factors can be either endogenous or exogenous to the state. ${ }^{73}$ Gellers' article investigates why Nepal adopted a constitutional environmental right in its 2007 Interim Constitution whereas Sri Lanka did not enact such a right in its 1978 Constitution or its 2000 Draft Constitution. ${ }^{74}$

In the case of Nepal, the results of Gellers' analysis reveal that environmental rights came to acquire constitutional status because of a 'compelling suite of temporally bound conditions', which included political dynamics before and during the constitution-drafting process, historical events and international influences. ${ }^{75}$ The process was therefore more than the result of mere constitutional borrowing or policy convergence. ${ }^{76}$ One contextual factor was a history of unchecked environmental degradation and deforestation, dating back to at least the 1970s, which resulted in serious flooding and water pollution. This raised public consciousness about environmental issues and public demands for the government to address the environmental problems through law, and specifically through environmental constitutional provisions. ${ }^{77}$

In the case of Sri Lanka, Gellers' analysis indicates that different reasons explain the absence of environmental rights in both the 1978 Constitution and the 2000 Draft Constitution. However, both sets of reasons are largely related to domestic political dynamics. ${ }^{78}$ The exclusion of environmental rights was not deliberate in the case of the 1978 Constitution; instead, the drafters focused on legalizing civil and political rights. ${ }^{79}$ In the case of the 2000 Draft Constitution, there was insufficient demand for such rights. There was also a widespread sentiment that the judiciary was sympathetic to environmental public interest litigation and provided adequate redress for environmental grievances, which arguably

71 J. Gellers, 'Environmental Constitutionalism in South Asia: Analyzing the Experiences of Nepal and Sri Lanka' (2015) 4(2) Transnational Environmental Law, pp. 395-423, at 395.

72 Ibid., at p. 396.

73 Ibid., at p. 420, Table 2.

74 Ibid., at p. 398, n. 20.

75 Ibid., at p. 408.

76 Ibid., at p. 402.

77 Ibid., at p. 404.

78 Ibid., at p. 411.

79 Ibid. 
reduced the need to pursue constitutional solutions to manage environmental problems. ${ }^{80}$ The Sri Lankan environmental legal framework was also viewed as being sufficiently robust such that constitutional rights were unnecessary. ${ }^{81}$ Gellers' conclusions build on the findings of a previously conducted global statistical analysis: 'the likelihood that a country will adopt a constitutional environmental right is directly associated with its domestic political conditions and structures, and indirectly associated with the international normative context in which its constitution is written'. 82

\section{CONCLUSION}

The articles in this issue of TEL collectively embody progressive approaches towards environmental scholarship. The issue begins with a historically grounded and thought-provoking account of what sustainable development is meant to be and ought to be about, and ends with a rare example of social sciences research techniques deployed to shed light on legal phenomena. Each article considers how law is part of the solution of contemporary environmental challenges around the world, unified by the common quest to document and analyze these challenges and solutions through the lens of transnational environmental law.

The contributions in this issue of TEL amply illustrate the growing strength and intellectual rigour of the field. TEL's recently awarded first impact factor, an impressive 0.559 achieved within four years of its launch, affirms the importance of the endeavour. With this, TEL ranks as the third environmental law journal worldwide in its first year of inclusion in Thomson Reuters' Journal Citation Reports. Earlier this year, TEL achieved the same position among environmental law journals listed in Scopus' Global Law Journal Ranking 2014. These achievements would not be possible without the support of contributors, reviewers, the growing TEL team and, last but not least, our expanding network of followers, friends, connections, tweeters and re-tweeters. Most importantly, we thank our growing readership, who continue to inspire the development of TEL as a forum for innovative environmental law scholarship.

Editors-in-Chief

Thijs Etty

Veerle Heyvaert

Editors
Wil Burns
Cinnamon Carlarne
Dan Farber
Jolene Lin

80 Ibid., at p. 415.

81 Ibid., at p. 417.

82 Ibid., at p. 420. 